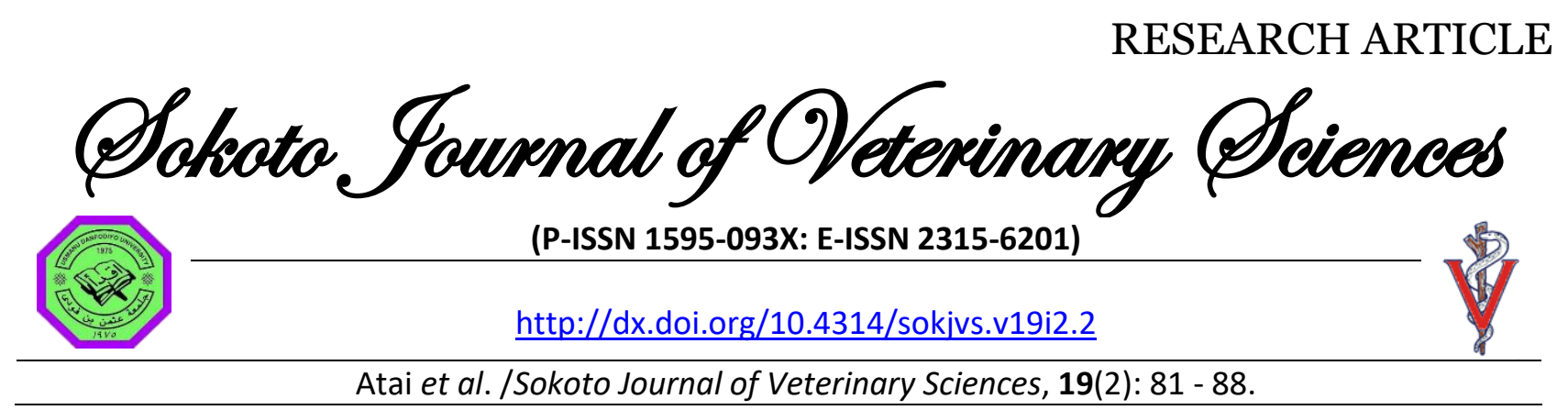

\title{
Epidemiological features of lumpy skin disease outbreaks amongst herds of cattle in Bokkos, north-central Nigeria
}

\author{
RB Atai ${ }^{1 *}$, OS Olaolu ${ }^{2}$ JA Adole ${ }^{1}$, I Haruna ${ }^{3}$, SI ljoma ${ }^{1}$, NA Maurice ${ }^{1}$, DO Omoniwa ${ }^{4}$, \\ BB Dogonyaro ${ }^{1} \&$ AJ Adedeji ${ }^{1}$ \\ 1. National Veterinary Research Institute, Vom, Plateau State, Nigeria \\ 2. Nigerian Institute for Trypanosomiasis Research, Plateau State, Nigeria \\ 3. Federal College of Animal Health and Production Technology, Vom Plateau State, Nigeria \\ 4. Department of Veterinary Medicine, Surgery and Radiology, Faculty of Veterinary Medicine, University of \\ Jos, Plateau State Nigeria
}

*Correspondence: Tel.: + 2348036397746; E-mail: beckybitiyong@gmail.com

\begin{abstract}
Copyright: (C) 2021 Atai et al. This is an openaccess article published under the terms of the Creative Commons Attribution License which permits unrestricted use, distribution, and reproduction in any medium, provided the original author and source are credited.
\end{abstract}

Publication History: Received: 25-10-2020 Revised: 03-02-2021 Accepted: 07-02-2021

\section{Abstract}

Lumpy Skin Disease (LSD) is a severe viral transboundary disease of mostly cattle caused by LSD Virus (LSDV). This epidemiological survey of LSD amongst herds of cattle in Bokkos Local Government Area (LGA) of North Central Nigeria was carried out in 2019 as a response to farmers' reports of repeated outbreaks of LSD in their herds of cattle. A focused group discussion with cattle farmers purposefully selected was used for the disease investigation and data collection. Twelve skin scab samples were collected from suspected cases within the study area. The viral attachment protein gene of the LSDV was amplified using polymerase chain reaction (PCR). Analysis of the focus group discussion revealed that all farmers interviewed practiced extensive farm management system and claimed that their animals shared same communal water points and grazing area. Furthermore, 47\% (7/15) of the farmers have experienced LSD twice in their herds, while $27 \%(4 / 15)$ have had the outbreak thrice on their farms. The morbidity rates of LSD were $3 \%-49 \%$ and mortality rates were $1 \%-6 \%$. Sixty percent of farmers claimed that incidence of LSD is related to season of the year. All farmers sell off their sick animals in the livestock market and confirmed LSD affects market price of their animals. PCR results revealed that in 91.6\% (11/12) samples analysed, LSDV was detected. This study confirms LSD outbreaks based on PCR result and clinical signs and symptoms in Butura, Daffo and Kunduk of Bokkos LGA, North Central Nigeria.

Keywords: Bokkos, Lumpy skin disease, Nigeria, Outbreak, Polymerase Chain Reaction

\section{Introduction}

Lumpy Skin Disease (LSD) is an economically important transboundary disease of cattle and water buffalos caused by LSD virus (LSDV) (Tuppurainen \& Oura, 2012; Limon et al., 2020). The LSDV belongs to 
the family Poxviridae and genus Capripoxvirus; other members are sheep pox and goat pox viruses (Tuppurainen et al., 2017b). Capripoxviruses are species-specific but cannot be differentiated serologically except through molecular assays (Tulman et al., 2001). Cattle of all ages and breeds may be infected, but the severity of the disease is higher in naive exotic breeds (Ardestani \& Mokhtari, 2020). The morbidity is usually around $10-14 \%$ while mortality ranges between $1 \%$ and $5 \%$ in endemic areas (Babiuk et al., 2008; Adedeji et al., 2017; Ochwo et al., 2020). The characteristic clinical signs of LSD include lacrimation, fever $\left(40-41^{\circ} \mathrm{C}\right)$, lymphadenopathy and nodular skin lesions that progress to sitfast lesions, which can persist for many months (Babiuk et al., 2008; Adedeji et al., 2019). In some LSD outbreaks, affected animals develop swelling of one or more legs, lameness and edema of the dewlap (Tuppurainen et al., 2005; Tuppurainen \& Oura, 2012). Emaciation of infected animals and a convalescence period lasting several months cause a decreased growth rate in beef cattle (Ayelet et al., 2014). The LSDV is transmitted mechanically by biting insects, while transmission by contact is postulated not to be effective (Sprygin et al., 2019). To date, the most likely vectors for LSDV transmission are blood-sucking arthropods such as stable flies (Stomoxys calcitrans), mosquitoes (Aedes aegypti), and hard ticks (Rhipicephalus and Amblyomma species) (Kahana-Sutin et al., 2017; Sprygin et al., 2019; Sohier et al., 2019). However, the virus can be transmitted indirectly through sharing of feeding and drinking troughs as well as suckling infected dams by calves (Tuppurainen et al., 2017a; Sprygin et al., 2019).

There is plethora of available tests for the confirmation of LSD, including viral isolation, serology, histopathology, immunohistochemistry and molecular assays such as polymerase chain reaction (PCR) (Haegeman et al., 2019). But PCR, either conventional or real time, is the most used and probably the most sensitive but costly to carry out particularly in resource limited countries (Haegeman et al., 2019). LSD was previously endemic only to Africa since the first report in Zambia in 1929, but due to the transboundary nature of the LSDV, by 2013 it has spread to the Middle Eastern countries of Israel, Jordan, Lebanon, Kuwait, Saudi Arabia, Iraq, Iran, Oman, Yemen, United Arab Emirates and Bahrain (Tuppurainen et al., 2017b). Thereafter, from 2013 - 2016, it was reported in several European countries including Turkey, Georgia, Cyprus and the Balkan countries (Tuppurainen et al., 2017b). Recently the disease has advanced to East Asian countries of China, India, Taiwan and Nepal (Calistri et al., 2019; Acharya \& Subedi, 2020; Ardestani \& Mokhtari, 2020; Sudhakar et al., 2020). Lumpy skin disease is capable of causing high economic losses as a result of chronic debilitating illness in affected cattle, loss in milk production, infertility, abortion, deaths and trade restrictions. Other direct economic losses include damage to hide and skin, costs of vaccination and stamping out (Tuppurainen et al., 2017b). LSD was first reported in Nigeria by Woods (1974), and later by Bida et al. (1976). Thereafter, reports from other parts of the country particularly in nomadic herds and organized farms were documented (Nawathe et al., 1982; Adedeji et al., 2019). Outbreaks of LSD occur yearly particularly in transhumant cattle herds with severe economic losses such as deaths and reduced market value of animals (Limon et al., 2020). Therefore, this study was designed as a response to farmers' reports of repeated outbreaks of LSD and as a preliminary survey amongst cattle herds in Bokkos LGA, North Central Nigeria.

\section{Materials and Methods \\ Study area}

The study was carried out in Bokkos, one of the 17 Local Government Areas (LGA) of Plateau State. Bokkos LGA is located on latitude $9^{\circ} 18^{\prime} 00^{\prime \prime} \mathrm{N}$ and longitude $9^{\circ} 00^{\prime} 00^{\prime \prime} \mathrm{E}$. It occupies a land mass of 1682 $\mathrm{km}^{2}$ and population of 178,454 people based on the 2006 census (Ayinya et al., 2018). The major occupation of the residents is livestock and crop production (Idehen et al., 2019). The commonly kept livestock are cattle, sheep and goats. These animals are kept on semi-intensive and extensive husbandry systems. The Bokkos LGA has a cattle migration route through which animals are moved to southern parts of Nigeria in search of pasture. The migrating herds interact with sedentary herds in the study area in the course of their journey. Some of the villages in Bokkos LGA are Butura, Tanti, Ganda, Kunduk and Daffo which are part of Bokkos, Daffo and Toss Districts (Figure 1).

\section{Study design}

The study was designed in response to reports of repeated outbreaks of LSD in Butura of Bokkos LGA, a qualitative survey was carried out in areas of Butura, Daffo and Kunduk (Figure 1) where cattle farmers had previously reported outbreaks of LSD to the veterinary authorities to investigate the outbreaks, collect data on risk factors, farm management practices, effect of LSD on livelihood of farmers and samples for laboratory confirmation of the outbreak. From October 2019 to November 
2019, a purposive sampling method was used to select 15 cattle farmers from Bokkos LGA after which their consent and approval to participate in the survey was sought. A participatory rural appraisal method through focus group discussion with farmers was used for the investigation. Farmers' recognition of the disease was aided with coloured plates showing classical LSD cases.

\section{Data collection}

A checklist of questions on types of diseases affecting animals, livestock husbandry system, familiarity with LSD, morbidity and mortality, sharing of grazing and watering points, incidence of LSD in herds, clinical signs, sources of infection, effect of LSD on market prices of animals, and risk factors were used as a guide for the discussion.

Field investigation and sample collection: In 2018, three villages in Bokkos LGA had
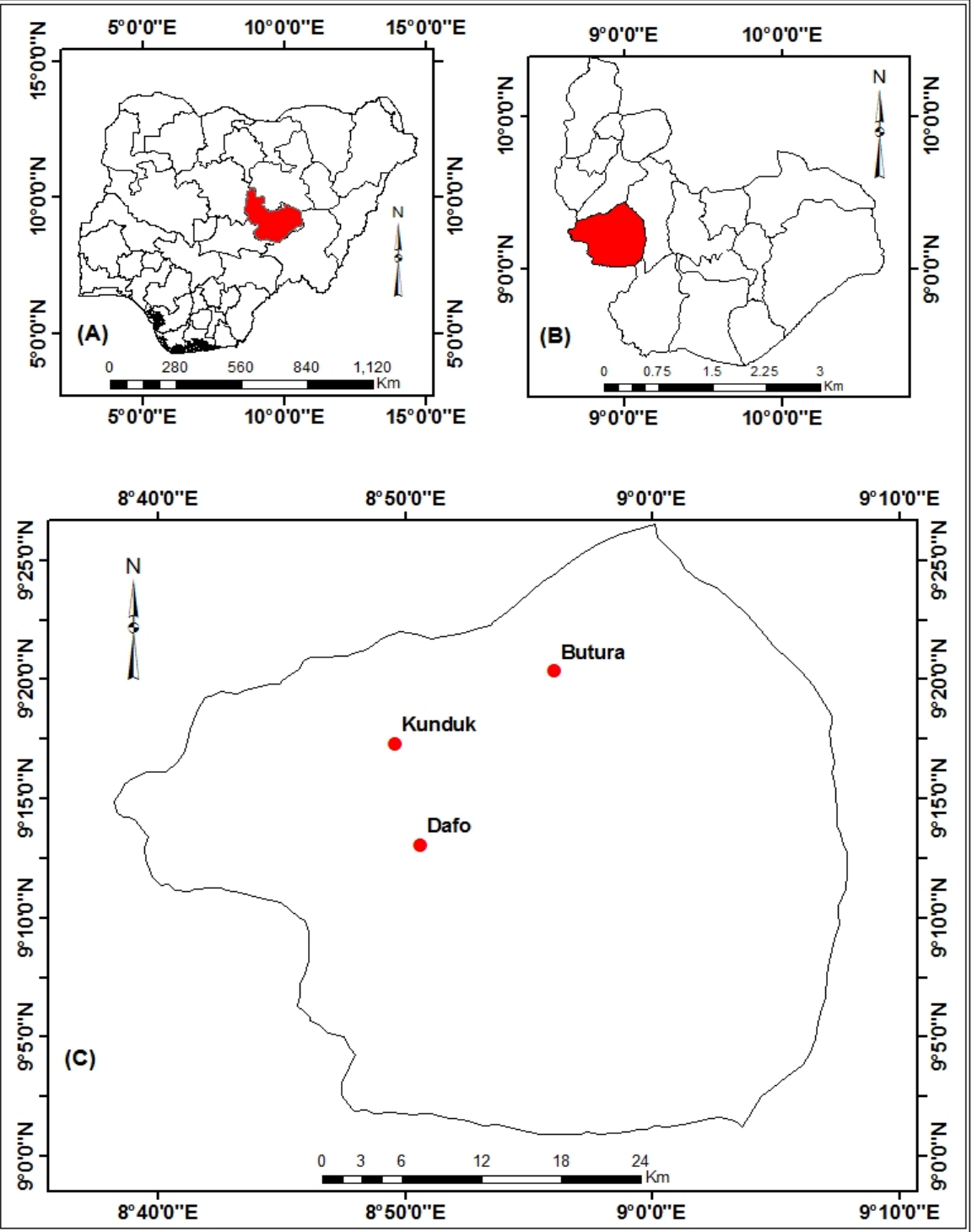

Figure 1: A: Map of Nigeria showing Plateau State; B: Map of Plateau State showing Bokkos, the study area and C. Map of Bokkos LGA showing three locations where the study was carried out

Source: Environmental Systems Research Institute, 2020 suspected LSD outbreaks from September to

December. Also, in 2019, five suspected LSD outbreaks were reported in the same local government within the same months. Three villages (Butura, Daffo and Kunduk) of the five were used in this survey due to security reasons and inaccessible roads. Clinical signs observed were lameness, nodular skin lesions and oedema of the dewlap. Twelve skin scab samples were collected from five cattle herds showing pathognomonic signs of LSD particularly nodular skin lesions (Plates IA-C). The age of the affected animals were 4 months to 6 years and all the cattle were White Fulani. The samples were transported on ice to the Viral Skin Diseases Laboratory, NVRI, Vom and stored at $20^{\circ} \mathrm{C}$ until required for analysis.

\section{Laboratory analysis}

Total DNA was extracted from scab sample homogenates using the QIAamp DNA mini kit (Qiagen, Hilden Germany). The DNA extracts were subjected to conventional PCR to amplify viral attachment gene (VP32) of the LSDV using primers 
designed by Ireland and Binepal (1998). Briefly, the reaction mixture consisted of $14.0 \mu \mathrm{l}$ of $\mathrm{H}_{2} \mathrm{O}, 2.5 \mu \mathrm{l}$ $10 \times$ taq buffer with $(\mathrm{NH} 4) \mathrm{SO}_{4}, 3.0 \mu \mathrm{l} \mathrm{MgCl}_{2}, 0.5 \mu \mathrm{l}$ dNTPs, $1.0 \mu \mathrm{l}$ of each primer, $0.5 \mu \mathrm{l}$ Taq DNA polymerase and $2.5 \mu \mathrm{l}$ DNA template. The PCR conditions were as follows: $94^{\circ} \mathrm{C}$ for $2 \mathrm{~min}$ initial denaturation, followed by 35 cycles of $94^{\circ} \mathrm{C}$ for $40 \mathrm{~s}$, $55^{\circ} \mathrm{C}$ for $30 \mathrm{~s}, 72^{\circ} \mathrm{C}$ for $30 \mathrm{~s}$ and final elongation at $72^{\circ} \mathrm{C}$ for $5 \mathrm{~min}$ (Adedeji et al., 2018). The electrophoresis of PCR products was done on $1.5 \%$ agarose gel stained with ethidium bromide at $100 \mathrm{~V}$ for 30min and a 100bp ladder (New England Biolabs) was used as DNA marker. The positive control was LSD vaccine available at NVRI Vom, while the negative control was nuclease free water which were both subjected to DNA extraction and conventional PCR. After the run, the gel was viewed under UV light in a Syngene Bio-imaging system.

\section{Data analysis}

The data obtained from the focused group discussion were entered into Microsoft Excel (Microsoft Excel 2010) and results were presented in charts and table.
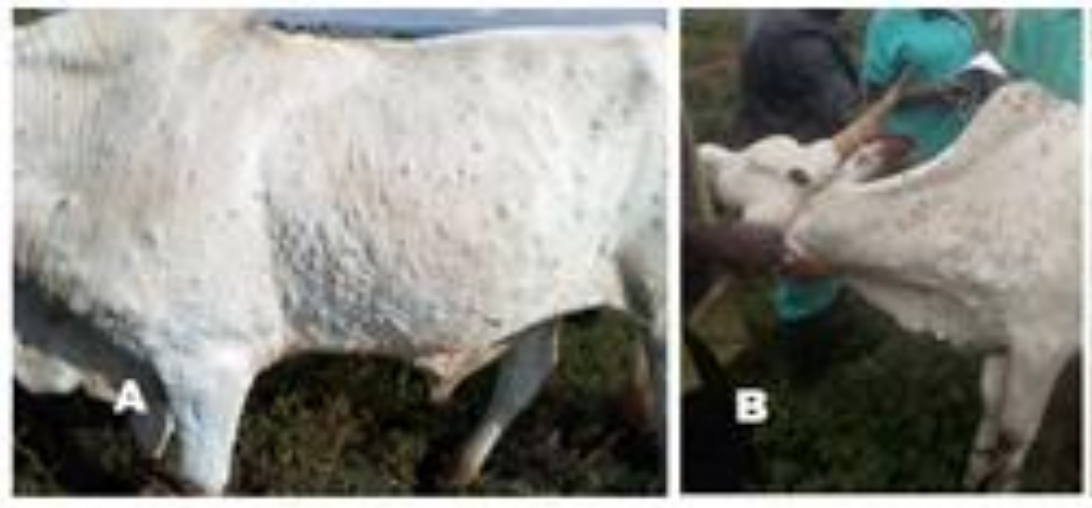

\section{Results}

Farmers ranked LSD and foot and mouth disease (FMD) as the most important diseases affecting their animals, while brucellosis and colibacillosis as the least important in this study (Figure 2). The data collected from farmers revealed that they all practiced extensive farm husbandry system and had experienced LSD in their herds of cattle at least once. Overall, total number of cattle owned by the 15 farmers that participated in the study was 1,164 in herd sizes of 35 - 150 cattle (Table 1). Majority (53\%) of the cattle farmers had herd sizes of $35-78$ animals, while $47 \%$ (7/15) of the farmers had herd size of 79 - 150 animals. The average herd LSD morbidity rate was $16 \%$ although the farmers claimed they had morbidity rate range of $3-46 \%$. Based on the data collected, the herd LSD mortality rate was $0-6 \%$ (Table 1 ). All the farmers claimed that their animals share communal water points and grazing areas. Results from the study further revealed that $47 \%(7 / 15)$ of the farmers had experienced LSD twice in their herds, while $27 \%$ $(4 / 15)$ have had the outbreak thrice in their farm (Figure 3). The PCR results revealed that in $91.6 \%$ $(11 / 12)$ of the samples analysed, the LSDV was detected at expected band size of 192bp (Plate II). The positive control was also amplified at

Plate I: A: A White Fulani bull with nodular skin lesions. B \& C: A white Fulani cow with subcutaneous nodules on the neck

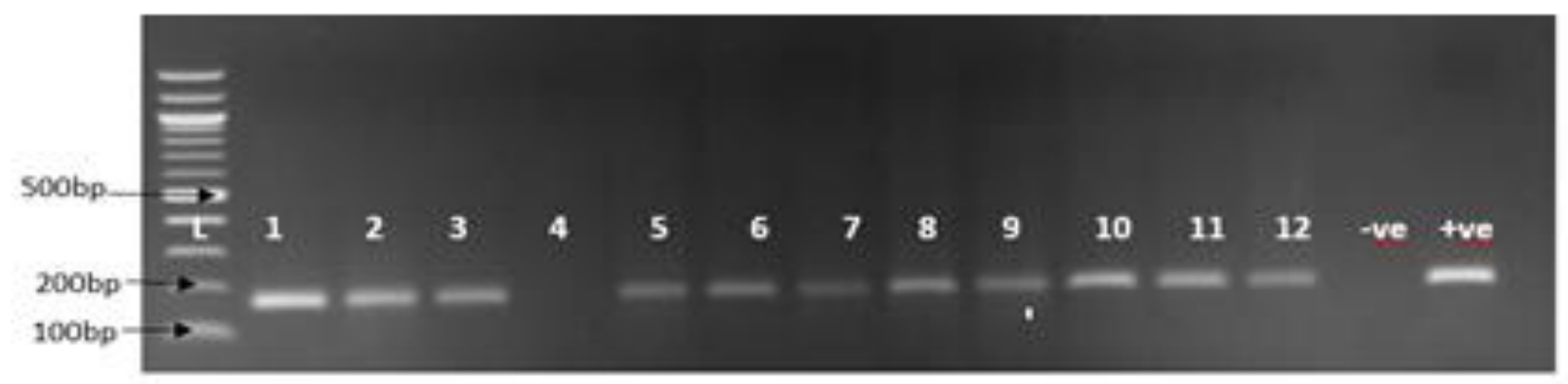

Plate II: Polymerase chain reaction product of viral attachment gene of LSD virus amplified at $192 \mathrm{bp} .1-12$ are samples collected during the study, + ve and - ve are positive and negative controls respectively. L is the DNA marker which is $100 \mathrm{bp}$ ladder 
the expected band size, while there was no amplification of the negative control. clinical signs of LSD observed by herders were anorexia, emaciation and nodular skin lesions in affected animals (Figure 4). In addition, 60\% (9/15) of farmers said the occurrence of the disease was related to season, $27 \%(4 / 15)$ said the presence of insect was a risk factor for having the disease while $6.6 \%(1 / 15)$ did not know the source of the infection (Figure 5).

All farmers sell off their sick animals affected with LSDV in the livestock market and have confirmed that the disease affects the selling price of the animals. All the farmers interviewed treat their animals by themselves without involving the animal health workers or veterinarians and mostly use Procaine penicillin, dexamethasone and long acting Oxytetracycline.

\section{Discussion}

Lumpy skin disease is endemic but neglected disease of cattle in Nigeria. This study was designed in response to repeated outbreaks of

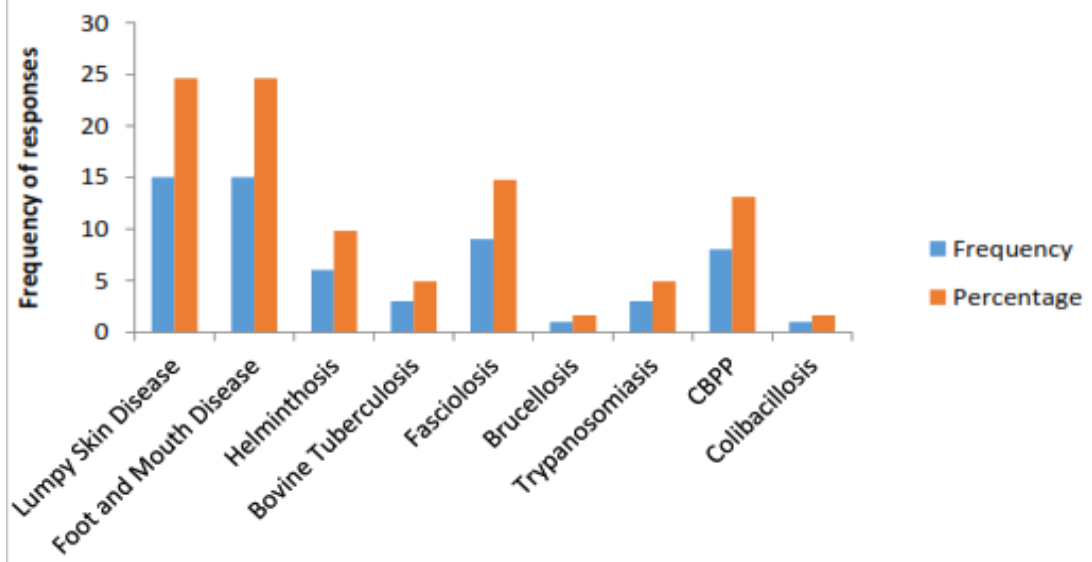

Figure 2: Ranking of common diseases of Cattle in Bokkos Local Government Area, North Central Nigeria based on data collected from farmers

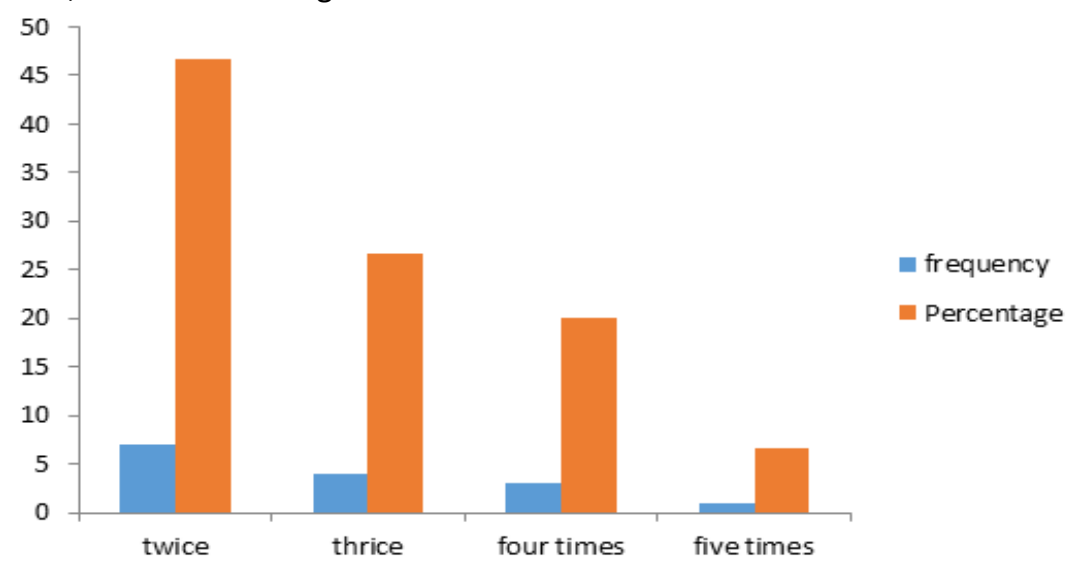

Figure 3: Farmers response on lumpy skin disease incidence in their cattle herds in Bokkos Local Government Area, North Central Nigeria

Table 1: Herd size and lumpy skin disease morbidity and mortality rate in cattle in Bokkos Local Government Area of Nigeria

\begin{tabular}{|c|c|c|c|c|c|}
\hline Farm ID & Herd size & Number affected & Morbidity rate & Number dead & Mortality rate \\
\hline 1 & 70 & 15 & $21 \%$ & 2 & $3 \%$ \\
\hline 2 & 63 & 20 & $32 \%$ & 3 & $5 \%$ \\
\hline 3 & 120 & 15 & $13 \%$ & 1 & $1 \%$ \\
\hline 4 & 92 & 7 & $8 \%$ & 3 & $3 \%$ \\
\hline 5 & 81 & 37 & $46 \%$ & 2 & $2 \%$ \\
\hline 6 & 150 & 5 & $3 \%$ & 1 & $1 \%$ \\
\hline 7 & 74 & 15 & $20 \%$ & 2 & $3 \%$ \\
\hline 8 & 84 & 20 & $24 \%$ & 4 & $5 \%$ \\
\hline 9 & 53 & 8 & $15 \%$ & 0 & $0 \%$ \\
\hline 10 & 104 & 6 & $6 \%$ & 2 & $2 \%$ \\
\hline 11 & 63 & 6 & $10 \%$ & 2 & $3 \%$ \\
\hline 12 & 47 & 5 & $11 \%$ & 1 & $2 \%$ \\
\hline 13 & 35 & 3 & $9 \%$ & 0 & $0 \%$ \\
\hline 14 & 48 & 10 & $21 \%$ & 3 & $6 \%$ \\
\hline 15 & 80 & 9 & $11 \%$ & 2 & $3 \%$ \\
\hline Total & 1164 & 181 & $16 \%$ & 28 & $2 \%$ \\
\hline
\end{tabular}


LSD in Bokkos LGA Plateau State, North Central Nigeria and it is the first of such study on LSD in the study area. Although LSD has been previously reported in other parts of Plateau State (Gambo et al., 2018; Ifende et al., 2019). The study identifies the epidemiological features and economic impact of LSD on subsistence smallholder cattle farmers in the study area. Livestock keeping is an important part of livelihood of rural people in Nigeria, because these animals are source of income, bank to save money, transportation and draught power for crop cultivation. Hence the impact of transboundary disease like LSD cannot be overemphasized. In this report, the main features of LSD outbreaks identified were morbidity and mortality rates of $3-46 \%$ and 0 - $6 \%$ respectively. Other epidemiological features include repeated outbreaks of LSD in the herds, seasonal incidence of the disease, extensive husbandry system with common grazing/water points. Interestingly, farmers that participated in the study claimed LSD is as important as FMD probably

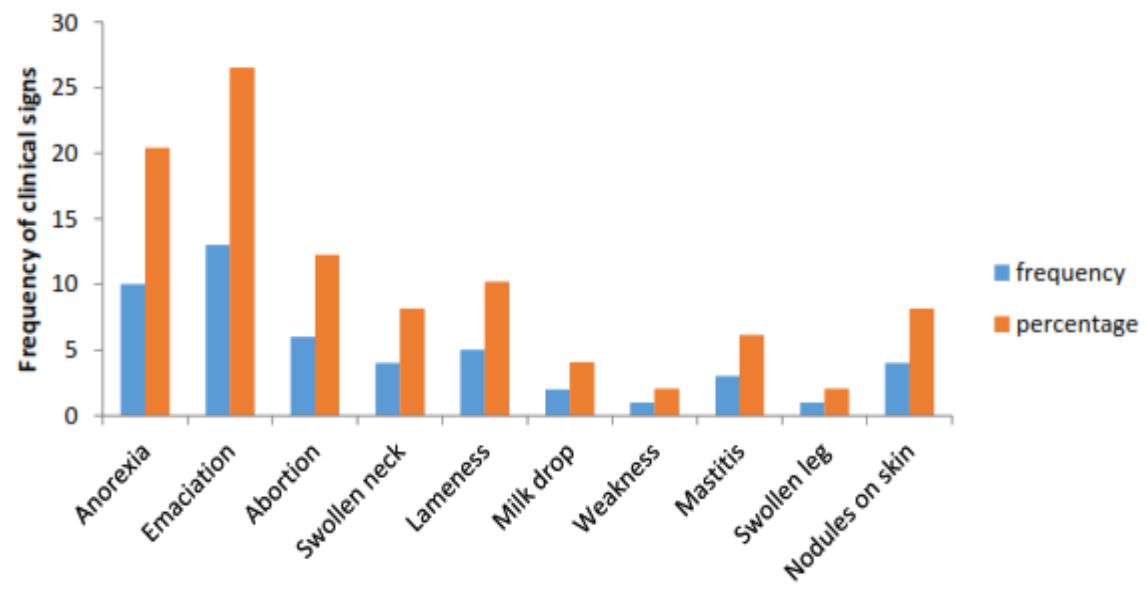

Figure 4: Clinical signs of lumpy disease skin observed by farmers in Bokkos Local Government Area, North Central Nigeria

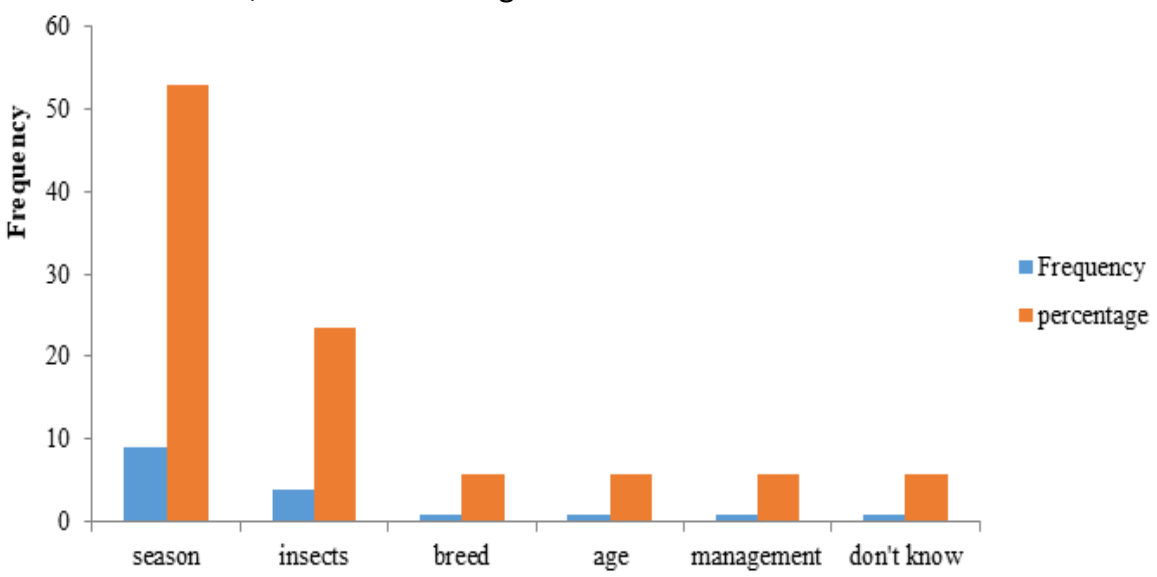

Figure 5: Farmers perceived risk factors of lumpy skin disease in Bokkos local government area, North Central Nigeria due to the impact of the disease on their herds. In previous studies in Nigeria, majority of cattle herders/pastoralists were familiar with LSD and the common name of the disease amongst transhumance herders is 'Bollo' which shows the disease may be endemic, but neglected (Gambo et al., 2018). Over all morbidity of $16 \%$ and mortality rate of $2 \%$ was obtained in this study which is higher than the report of Adedeji et al. (2018) with morbidity rate of $6.25 \%$, but mortality rate of $2.5 \%$. However, Gambo et al. (2018) reported a higher morbidity of $8-30 \%$ and $1-16.6 \%$ in southern parts of Plateau State, Nigeria. Laboratory analysis of scab samples by conventional PCR which amplified the viral attachment gene (VP32) of LSDV confirms presence of LSD with detection of the virus in $91.6 \%$ of the samples analysed. The positive samples were from Butura, Daffo and Kunduk all within the study area.

Conclusively, LSD outbreaks were confirmed based on PCR result and clinical signs and symptoms in Butura, Daffo and Kunduk of Bokkos LGA, North Central Nigeria. This study demonstrates that LSD has immediate effects on subsistence farmers' livelihoods. Also, we identified some risk and management factors associated with LSD in the study area. There is a need for farmers to be educated on the methods of transmission of LSD, preventive measures and the benefits of quarantine before introducing new animals into their cattle herds. Therefore, we recommend that farmers should report LSD outbreaks to veterinary authorities for proper intervention and control measures.

\section{Conflicts of Interest}

The authors declare no conflict of interest. 


\section{References}

Acharya KP \& Subedi D (2020). First outbreak of lumpy skin disease in Nepal. Preventive Veterinary Medicine, 102(4): 274-283.

Adedeji AJ, Adole JA, Dogonyaro BB, Kujul N, Tekki IS, Asala OO, Chima NC, Dyek YD, Maguda AS \& Aba-Adulugba EP (2017). Recurrent Outbreaks of lumpy skin disease and its economic impact on a dairy farm in Jos, Plateau State, Nigeria. Nigerian Veterinary Journal, 38(2): 151-158.

Adedeji AJ, Akanbi OB, Adole JA, Chima NC \& Baje M (2018). Outbreak of lumpy skin disease in a dairy farm in Keffi, Nasarawa State, Nigeria. Sokoto Journal of Veterinary Sciences, 16(3): 80-86.

Adedeji AJ, Möller J, Meseko CA, Adole JA, Tekki IS, Shamaki D \& Hoffmann B (2019). Molecular characterization of Capripox viruses obtained from field outbreaks in Nigeria between 2000 and 2016. Transboundary and Emerging Diseases, 66(4): 1631-1641.

Ardestani EG \& Mokhtari A (2020). Modeling the lumpy skin disease risk probability in central Zagros Mountains of Iran. Preventive Veterinary Medicine. doi.10.1016/i.prevetmed.2020.

Ayelet G, Haftu R, Jemberie S, Belay A, Gelaye E, Sibhat B, Skjerve E \& Asmare K (2014). Lumpy skin disease in cattle in central Ethiopia: Outbreak investigation and isolation and molecular detection of lumpy skin disease virus. Revue Scientifique et Technique (International Office of Epizootics), 33(3): 1-23.

Ayinya GM, Gube IE \& James GS (2018). Uptake and Bioaccumulation of selected heavy metals in selected vegetables in Bokkos local Government Area, Plateau State. International Journal of Trend in Scientific Research and Development, 3(1): 917-921.

Babiuk S, Bowden T, Boyle D, Wallace D \& Kitching R (2008). Capripoxviruses: An emerging worldwide threat to sheep, goats and cattle. Transboundary and Emerging Diseases, doi.10.1111/j.18651682.2008.01043.x

Bida SA, Ali II, Eid FIA \& Mustapha HB (1976). Lumpy skin disease outbreak in cattle of Northern Nigeria. Journal of Nigerian Veterinary Medical Association, 5: 21-26.

Calistri P, DeClercq K, Gubbins S., Klement E, Stegeman A, Cortiñas Abrahantes J, Antoniou SE, Broglia A \& Gogin A (2019).
Lumpy skin disease: III. Data collection and analysis. European Food Safety Authority, doi.10.2903/j.efsa.2019.5638.

Gambo P, Maguda AS, Adole JA, Dyek DY, Ifende VI, Bot C \& Adedeji AJ (2018). A survey of viral diseases of livestock characterized by skin lesions in Kanam Local Government Area of Plateau State, Nigeria. Nigerian Veterinary Journal, 39(3): 250-262.

Haegeman A, De Vleeschauwer A, De Leeuw I, Vidanović D, Šekler M, Petrović T, Demarez C, Lefebvre D \& De Clercq K (2019). Overview of diagnostic tools for Capripox virus infections. Preventive Veterinary Medicine, doi.10.1016/j.prevetmed.2019.

Idehen CO, Obaloto OO, Opabunmi RO, Olaleye OO, Bongaby GA, Aluma LA, Gbadamosi F \& Ikyase CT (2019). Dry season prevalence of bovine African trypanosomosis in parts of Bokkos Local Government Area of Plateau State, Nigeria. Egypt Journal of Veterinary Science, 50(1): 75- 80.

Ifende VI, Maurice NA, Abbas Y, Agu C, Bolajoko B, Jambol A, Adole JA, Asala O, Wungak YS, Maguda A, Umeh E \& Adedeji AJ (2019). A retrospective study of viral skin diseases of cattle, sheep and goats in Plateau State, Nigeria. Sokoto Journal of Veterinary Sciences, 17(1): 49-55.

Ireland DC \& Binepal YS (1998). Improved detection of capripoxvirus in biopsy samples by PCR. Journal of Virological Methods, 74(1): 1-7.

Kahana-Sutin E, Klement E, Lensky I \& Gottlieb Y (2017). High relative abundance of the stable fly Stomoxys calcitrans is associated with lumpy skin disease outbreaks in Israeli dairy farms. Medical and Veterinary Entomology, 31(2): 150-160.

Limon G, Gamawa AA, Ahmed Al, Lyons NA and Beard PM (2020). Epidemiological characteristics and economic impact of lumpy skin disease, Sheeppox and Goatpox among Subsistence Farmers in Northeast Nigeria. Frontiers in Veterinary Science, 7(8): 1-13.

Nawathe DR, Asagba MO, Abegunde A, Ajayi SA \& Durkwa $L$ (1982). Some observations on the occurrence of lumpy skin disease in Nigeria. Zentralblatt fur Veterinarmedizin Reihe $B$, 29(1): 31-36.

Ochwo S, VanderWaal K, Ndekezi C, Nkamwesiga J, Munsey A, Witto SG, Nantima N, Mayanja F, Okurut ARA, Atuhaire DK \& Mwiine FN (2020). Molecular detection and 
phylogenetic analysis of lumpy skin disease virus from outbreaks in Uganda 2017-2018. BioMed Central Veterinary Research, 16(66): 1-10.

Sohier C, Haegeman A, Mostin L, De Leeuw I, Campe WV, De Vleeschauwer A, Tuppurainen E, van den Berg T, De Regge N \& De Clercq $\mathrm{K}$. (2019). Experimental evidence of mechanical lumpy skin disease virus transmission by Stomoxys calcitrans biting flies and Haematopota spp. horseflies. Scientific Reports, doi.10.1038/s41598-01956605-6.

Sprygin A, Pestova Y, Wallace DB, Tuppurainen E \& Kononov AV (2019). Transmission of lumpy skin disease virus: A short review. Virus Research, doi.org/10.1016/j.virusres.2019.05.015.

Sudhakar SB, Mishra N, Kalaiyarasu S, Jhade SK, Hemadri D, Sood R, Bal GC, Nayak MK, Pradhan SK \& Singh (2020). Lumpy skin disease (LSD) outbreaks in cattle in Odisha state, India in August 2019: Epidemiological features and molecular studies. Transboundary and Emerging Diseases, 67(5): 1-15.
Tulman ER, Afonso CL, Lu Z, Zsak L, Kutish GF \& Rock DL (2001). Genome of lumpy skin disease virus. Journal of Virology, 75(5): 7122-7130

Tuppurainen E, Alexandrov T \& Beltrán-Alcrudo D (2017b). Lumpy Skin Disease Field Manual-A Manual for Veterinarians. FAO Animal Production and Health Manual No. 20. Rome. Pp 13-32.

Tuppurainen ESM \& Oura CAL (2012). Review: Lumpy Skin Disease: An emerging threat to Europe, the middle east and Asia. Transboundary and Emerging Diseases, 59(1): 40-48.

Tuppurainen ESM, Venter EH \& Coetzer JAW (2005). The detection of lumpy skin disease virus in samples of experimentally infected cattle using different diagnostic techniques. Onderstepoort Journal of Veterinary Research, 72(2): 153-164.

Tuppurainen ESM, Venter EH, Shisler JL, Gari G, Mekonnen GA, Juleff N, Lyons NA, De Clercq K, Upton C Bowden TR, Babiuk S \& Babiuk LA (2017a). Review: Capripoxvirus Diseases: Current status and opportunities for control. Transboundary and Emerging Diseases, 64(3): 729-745.

Woods JA (1974). A skin condition of cattle. Veterinary Record, 95(14):326. 